\title{
PEDRO PAULO ABREU FUNARI AND THE STUdY OF ANTIQUITY
}

Hector Benoit ${ }^{1}$

The academic production of Professor Pedro Paulo Funari, from the University of Campinas (Unicamp), is so wide and has such quality that it would be futile to try to evoke it in its full extent. To attest this fact, it suffices to read his abridged on-line curriculum vitae at Plataforma Lattes.

I will seek, therefore, to focus on the academic relations Prof. Funari and I have nurtured over more than two decades as faculty members of the Institute of Philosophy and Human Sciences (IFCH) at Unicamp: Prof. Funari, on his turn, as a member of the Department of History, and myself as a member of the Department of Philosophy at the same institute.

I initially met him in the early 1990s, when we participated of the first Editorial Board of Revista Ideias, a periodical that exists to this day and presents the theoretical production of scholars from the IFCH departments. I promptly noticed his extraordinary competence and academic skills, with some virtues he continually displayed during our many years as colleagues: his punctuality and assiduity at meetings, his always attentive academic opinions, and his ability to cordially engage in discussions, while firmly asserting his own positions.

In February 1995, at the initiative of IFCH Director João Quartim de Moraes, the IFCH Fellowship decided to create its Internal Research and Documentation Centers. One of these many research centers was the Center for Ancient Classical and Hellenistic Thought, and its Historical Posterity (CPA). The CPA was an initiative of scholars from the Department of Philosophy. Among them, I recall Professor João Quartim de Moraes himself (more interested in modern and ancient Materialism, in particular the works of Democritus and Epicurus); Francisco Benjamin de Souza Netto (specialist in Medieval Philosophy and a great connoisseur of Aristotle and Plato); Carlos Arthur Ribeiro do Nascimento (an expert in Medieval Philosophy and also, obviously, a great

1 Associate Professor, State University of Campinas, Campinas, Brazil. E-mail: hbenoit@uol.com.br 
connoisseur of Ancient Classical thought); and myself as a specialist in Plato and Platonism interested in Ancient thought, dialectics and its historical posterity.

The inspiration behind my interest in the CPA as a setting for the study of Antiquity emerged from my 1993 internship period at Centre Louis Gernet, which was then led by Jean-Pierre Vernant, a close collaborator of Pierre Vidal-Naquet, with whom I had more contact. Vidal-Naquet initially published Le chasseur noir, followed by La démocratie grecque vue d'ailleurs. I was very impressed by the way his analyses show different uses of Antiquity in many historical epochs, i.e., how a diversity of ideological uses of Greek democracy occurred at different times. Vidal-Naquet portrays above all how the imagery of Greek democracy emerged in distinct ways, for instance, during the French Revolution, following the political positions of those who resorted to it.

Thus, before the CPA was founded, as its initial project was being discussed, we realized the relevant theoretical interest we would have in the contributions of experts in Ancient History and Archaeology. The name of Professor Pedro Paulo Abreu Funari, from the Department of History at IFCH, was promptly remembered, and he accepted the invitation to participate in this enterprise as Assistant Director, while I initially took up the position of CPA Director. Despite the fact that Prof. Funari dedicated himself to the study of Ancient History and Archaeology, he shared this view of the need to think the past also from the standpoint of its uses in the present.

By 1995, Prof. Funari and I were vigorously involved in the CPA activities. In that year, the CPA held its first Colloquium at IFCH. From then on, the Colloquium became a standing event for many years, and already in its first edition, we started to combine activities aimed at Ancient History and activities on Ancient Philosophy, while reflecting about the posterity of these areas. 20 editions of the CPA Colloquium were held since then, and the upcoming edition is provisionally scheduled for May 2018. The members of the colloquium's organizing committee started to hold monthly meetings, in addition to seminars with the participation of guest scholars from many Brazilian and international universities, and the contributions of undergraduate and graduate students from both departments. In 1996, we launched the (nearly) halfyearly periodical Boletim do CPA, which reached 21 issues in 2005. Starting on Issue 22/23 (a double issue), this publication was renamed Revista de Estudos Filosóficos e Históricos da Antiguidade, and it continues to be published to the present. Among the publications Professor Funari 
and I collaborated with, we organized the volume Ética e Politica na Antiguidade Clássica (Unicamp/FAPESP, 2001).

I also highlight the contributions of some scholars who have been in the CPA since its creation and are still collaborating with its activities, who are not IFCH faculty members but have other research links with Unicamp: Prof. Maria Carolina Alves dos Santos (from UNESP, now a faculty member at Faculdade do Mosteiro de São Bento) and Gérson Pereira Filho (PUC-MG). Dr. Pereira Filho is currently a post-PhD student under my supervision at Unicamp, and he is studying Plato's Laws in order to reflect on how some aspects of this work reappear in the Contemporary Age. Recent collaborators at the CPA include Robson Gabioneta, who holds an MSc degree in Ancient Philosophy from Unicamp, and André de Góes Cressoni, PhD in Ancient Philosophy from Unicamp and currently a post-PhD student under my supervision.

In our work to strengthen the CPA activities, Prof. Funari and I also established more solid internal relations with Unicamp's Institute of Language Studies (IEL). For a period of time, Prof. Flávio Ribeiro de Oliveira - currently IEL Director - was an active CPA participant, in addition to Prof. Patrícia Prata from the IEL, who served as CPA Director from 2011 until recently. IEL Professor Isabella Tardin Cardoso, who attained wide international experience and is now a guest researcher and lecturer at the Seminar für Klassische Philologie in Heidelberg, Germany, also collaborated and still contributes to the CPA.

During these years, a number of students were gradually integrated to the CPA - some of them, for a longer period of time, and others, eventually, collaborating with its periodical seminars, contributing to its publications and helping organize its colloquia, which were initially held on an annual basis, but later were held every two years. From our former students who were active participants, I remember Aparecido Gomes Leal, who served as CPA executive secretary for a long period, and José Silva Lima, editorial secretary of the first issues of Boletim do CPA (now, Associate Professor at the Federal University of Acre) who became prominent scholars in other universities, as well as Ronildo Alves dos Santos (USP-RP) and Reinaldo Sampaio Pereira (UNESP).

Many of Prof. Funari's students who are now teaching collaborated since their undergraduate years with the CPA activities. For instance, Fábio A. Hering, now faculty member of the Department of Museology at UFOPMG; Renata Senna Garraffoni, now faculty member of the Department of History at UFPR and a well-respected Brazilian specialist in classical studies; Glaydson José da Silva, professor of history at UNIFESP and a 
scholar with far-reaching editorial activities in history nationwide. Both Renata Garraffoni and Glaydson Silva participated in the volume Antiguidade como Presença: Antigos, Modernos e os Usos do Passado (2017).

At any rate, the effort of naming all scholars and students who participated in the CPA, starting with Prof. Funari and his pupils, would leave us with an unending list. It suffices to mention that Prof. Funari supervised 17 post-PhD studies, $35 \mathrm{PhD}$ theses and $42 \mathrm{MSc}$ dissertations.

Among the international researchers linked to Plato who gave lectures and held other activities as CPA visiting scholars were Nestor-Luís Cordero, professor from the Université de Rennes I and researcher for several years at the Centre Leon Robin, Paris; Franco Tabasttoni, from the Università degli Studi di Milano in Italy; and Samuel Scolnicov from the Hebrew University and President of the International Plato Society, 19982001; I also remember the former President of the International Plato Society, Thomas M. Robinson, Professor Emeritus of Philosophy and Classics at the University of Toronto. Scolnicov and Robinson played a very important role for the creation of the Brazilian Platonists Society (SBP), primarily centered on the CPA colloquia and on the meetings of the Working Group on Plato and Platonism in connection with the National Postgraduate Philosophy Association (ANPOF). I coordinated these meetings for a considerable period of time, assisted by professors Maura Iglésias (PUC-RJ), Miguel Spinelli (UFSM-RS), Fernando Muniz (UFF-RJ) and JAA Torrano (USP).

Further on, with Professor Funari's help, Prof. Gabriele Cornnelli became a CPA collaborator, initially at Universidade Metodista and later as a faculty member of the University of Brasilia (UnB). Gabriele Cornelli's participation at the CPA was decisive to propel the SBP's expansion, until he was elected President of the International Plato Society (2013-2016), which brought its traditional international symposium for the first time to a Latin American country - to the city of Brasilia. This achievement definitely served to validate Brazil as an international reference in the field of Classical Studies.

All this was only possible as a result of the far-reaching links established by the CPA in international classical studies since its creation, by means of many researchers, colloquia and publications. And Professor Pedro Paulo Funari largely contributed with its efforts. In this regard, I highlight the importance of the international dimension in his personal academic training, which laid the ground for several truly solid contacts with researchers from many countries. The following information from 
his curriculum vitae summarizes his extensive international training experience:

2013 - 2013 - Post-PhD studies

Stanford University, Stanford, United States

Scholarship holder, Stanford University, SU, United States

Major: Human Sciences

2009 - 2009 - Post PhD studies

Stanford University, Stanford, United States

Scholarship holder, National Council for Scientific and Technological Development (CNPq), Brazil

Major: Human Sciences

Major: Human Sciences / Field: Archaeology

Major: Human Sciences / Field: Archaeology / Subfield: Historical Archaeology

2009 - 2009 - Post PhD studies

Durham University, Durham, Great Britain

Scholarship holder, National Council for Scientific and Technological Development (CNPq), Brazil

Major: Human Sciences

Major: Human Sciences / Field: Archaeology

Major: Human Sciences / Field: Anthropology

2008 - 2008 - Post PhD studies

Université de Paris X, Nanterre, Paris X, France 
Scholarship holder, National Council for Scientific and Technological Development (CNPq), Brazil

Major: Human Sciences

Major: Human Sciences / Field: Archaeology

Major: Human Sciences / Field: Archaeology / Subfield: Historical Archaeology

1998 - 1999 - Post PhD studies

Universitat de Barcelona, UB, Spain

Scholarship holder, Universitat de Barcelona, UB, Spain

Major: Human Sciences

Major: Human Sciences / Field: Archaeology / Subfield: Historical Archaeology

Major: Human Sciences / Field: Archaeology

1996 - 1997 - Post PhD studies

University College London, UCL, Great Britain

Scholarship holder, World Archaeological Congress, WAC, Great Britain

Major: Human Sciences

Major: Human Sciences / Field: Archaeology / Subfield: Historical Archaeology

1994 - 1995 - Post PhD studies

Universitat de Barcelona, UB, Spain

Major:

Human

Sciences

Major: Human Sciences / Field: Archaeology / Subfield: Historical Archaeology 
Major: Human Sciences / Field: Archaeology

1992 - 1993 - Post PhD studies

University College London, UCL, Great Britain

Scholarship holder, World Archaeological Congress, WAC, Great Britain

Major: Human Sciences

Major: Human Sciences / Field: Archaeology

Major: Human Sciences / Field: Archaeology / Subfield: Historical Archaeology

\section{1 - 1992 - Post PhD studies}

Illinois State University, ILSU, United States

Scholarship holder, Illinois State University, ISU, United States Major: Human Sciences Major: Human Sciences / Field: Archaeology / Subfield: Historical Archaeology

1989 - 1989

Archaeological theory

University College London, UCL, Great Britain

$1988-1988$

Archaeology of Roman amphorae

Universidad de Barcelona, UB, Spain

$1988-1988$

Roman amphorae 
University of Southampton, Southampton, Great Britain

$1987-1987$

University Extension with Archaeological Fieldwork in Arva

Universidad Complutense de Madrid, UCM, Spain

From all that was mentioned above about Professor Pedro Paulo Funari and his academic legacy, I can only join the efforts of my colleagues who are organizing this utterly just tribute to his work; above all, because, as I mentioned earlier, Prof. Funari's contribution to Classical Studies is immense, and it greatly surpasses the few elements I cited in the lines of this text. 